\title{
Journal of Business and Industrial Mar
}

\section{Top managers' role in key account management}

\begin{tabular}{|r|l|}
\hline Journal: & Journal of Business and Industrial Marketing \\
\hline Manuscript ID & JBIM-08-2018-0243.R3 \\
\hline Manuscript Type: & Original Article \\
\hline Keywords: & $\begin{array}{l}\text { Key accounts, Top management, Management, Value added, Customer } \\
\text { relations, Marketing }\end{array}$ \\
\hline \multicolumn{2}{|l}{} \\
\hline
\end{tabular}

\section{SCHOLARONE Manuscripts}




\section{Top managers' role in key account management}

Purpose - This paper explores top managers' role in key account management.

Design/methodology/approach - The possible actions that could be performed by a top manager were investigated in twelve case studies. These actions were grouped into key account managers and teams, culture, engagement and knowledge, organizational structure/conditions, and customers and markets.

Findings - Top managers (TMs) informally evaluate teams and key account (KA) managers, stimulate a culture that favours the information's prospection, persuade managers in order to reduce their resistance, and improve organizational structure/conditions by inducing internal and external questioning. They also contact key customers' top managers to check on the changes required or to persuade them to change requirements, accept a higher price or redirect an unattractive order to competitors. They approve revisions on the key customers list, discuss with the key account manager how to redirect an unattractive opportunity to competitors, and try to improve gains even in attractive orders.

Research limitations/implications - Additional research beyond the provided exploratory study is needed to generalize the results. The findings contribute to improving the understanding of how TMs get involved in key account management, buyer-supplier relationship improvement, and increasing company profitability. They also unveil top managers' role in internal culture creation and team engagement.

Originality/value - When managing their KAs TMs seem to be sceptical, curious and pragmatic with their subordinates, as well as with the customers or competitors.

Keywords: Key Accounts, Top Managers, Management, Value Added, Customer Relations, Marketing 


\section{INTRODUCTION}

Key account management (KAM) consists of a strategy used by suppliers to improve their relationships with the most important customers (Brehmer and Rehme, 2009; Guenzi et al., 2007; Hald et al., 2009; Tzempelikos and Gounaris, 2015). KAM helps to promote new inter- and intraorganizational management practices (Storbacka, 2012) and to leverage change in strategy, skills, values, style, structure, staff and systems (Guenzi and Storbacka, 2015).

Top managers (TMs) are also named in literature as senior managers, senior executives (ALHussan et al., 2017) and CEOs (Adomako, 2017). TMs play a pivotal role in key account management (KAM) (Tzempelikos and Gounaris, 2015). According to the literature the strategic position occupied by TMs allows them to contribute in several ways to the performance improvement of their subordinates. These contributions includee coaching and rewarding (Tzempelikos, 2015). TMs can also use their power to influence the conditions that guide their subordinates' actions regarding their key accounts (KA). Such conditions embrace goals and procedures (Guesalaga, 2014; Zupancic, 2008), as well as the needed resources (Leischnig et al., 2018; Oliva, 2006). Other researchers have investigated TMs' contribution to the relationship established between their companies and KAs. Their findings have indicated that TMs can induce the use of customer knowledge (Salojärvi et al., 2010) to boost organizational readiness in servitization (Rabetino et al., 2017) or to create joint platforms for integrating technology into customer solutions (Chakkol et al., 2018). Another research stream has identified that TMs can help to remove internal resistance to KAM (Wilson and Woodburn, 2014) or leverage a little-formalized KAM programme (Marcos-Cuevas et al., 2014),

Despite the actions performed by TMs a B2B relationship may not last forever (Kamp, 2005). In general, the connections may be interrupted when the objective of one actor is not achieved (Corsaro and Snehota, 2011; Murfield and Esper, 2016) or when some event outside the product or service is observed (Hollmann et al., 2015). The literature also indicates that a change of one actor in the course of a B2B relationship influences the future behaviours of the other actors (Corsaro and Snehota, 2010) and that the attractiveness and adaptations performed by the buyer and supplier are interlinked in a mutually reinforcing or deteriorating manner (Makkonen et al., 2016). In such a context the interruption may be generated solely by the supplier or the buyer. Research findings have indicated that interruptions might occur when a buyer identifies a new alternative to improve its gains (Crosno et al., 2015; Pick and Eisend, 2014). On the supplier's side interruptions have been observed when KAs become less attractive compared to other types of accounts (Sharma and Evanschitzky, 2016). Reductions in buyer attractiveness have been observed when demands increase suppliers' costs (Niraj et al., 2008), reduce the supplier's focus on other priorities (Pache and Santos, 2010) or when demands 
cause changes in the supplier's operations (Crosno et al., 2015) or sales processes (Viio and Grönroos, 2015).

The analysis of the studies presented above suggests that KAM is strategic for suppliers, that TMs play a pivotal role in KAM, and that a buyer/supplier may change its objectives over time. Such changes may affect suppliers in a negative or positive way. Despite the prominent position occupied by TMs in supplying companies, however, the literature is almost silent on how such executives manage key accounts (KAs). To fill this gap this study investigates the following research question:

$$
R Q-\text { What is the role of TMs in KAM? }
$$

The empirical part of this paper is based on qualitative case study research of 12 cases. The literature review focuses on the actions that can be performed by TMs. Such actions are presented in the literature and were grouped into KA managers and teams, culture, engagement and knowledge, organizational structure/conditions, and KAs and markets. The study aimed to identify TMs' role in subordinate management, as well as in the improvement of a company's knowledge, internal structure, buyer-supplier relationships and gains. The remainder of this study is organized as follows: Section 2 presents actions that can be performed by TMs in KAM. Section 3 describes the qualitative empirical research on the cases. It also gives details about the case selection. Section 4 shows the findings. Section 5 presents the discussion of these findings. Section 6 presents a summary of the theoretical contribution, managerial implications, research limitations and suggestions for further studies. 


\section{KEY ACCOUNT MANAGEMENT}

This literature review shows where to focus on improving KAM. Considering that such focuses could attract TMs' attention when managing KAs, the literature was grouped into KA managers and their teams, culture, team engagement, and knowledge, organizational structure/conditions, and customers and markets. The first and second group indicate what TMs can do improve their managers' and teams' performance. The third group indicates what may interest them regarding the organizational structure/conditions of their own companies. The fourth group indicates ways to improve relationships with KAs. Details on these groups are presented below.

\section{Managers and teams}

Paying attention to KA managers and their teams is mandatory in KAM. The literature on KA managers presents roles, profiles and ways to improve their performance, as well as ways to mitigate short-term orientation. The literature on teams presents their importance and the requirements for improving their performance. Details about KA managers and their teams are provided below.

KA managers are responsible for identifying, analysing and selecting suitable relationship strategies for KAs (Georges and Eggert, 2003; Ojasalo, 2001). Considering these responsibilities, one study suggests that suppliers should pay attention to the executives who manage their key accounts (Abratt and Kelly, 2002). So, suppliers should consider the profile of the KA manager hired, ways to improve his/her performance, and mitigation of short-term orientation. Regarding profiles, the literature indicates that KA managers should present abilities to communicate, influence and persuade TMs to get involved with KAM (Pardo et al., 2014). Improvement in KA managers' performance should focus on the personal relationships established by these managers (Gounaris and Tzempelikos, 2014; Sharma, 2006). Suppliers should also focus on how KA managers identify ways to satisfy KAs (Sharma, 2006), and on their actions in customer-oriented selling, adaptive selling or team selling (Guenzi et al., 2007). The short-term orientation presented by some KA managers may lead to insufficient consideration of the strategic consequences of their decisions for the buyer-supplier relationship (Davies and Ryals, 2013). The mitigation of this short-term orientation requires the establishment of performance indicators linked to appropriate goals (Atanasova and Senn, 2011; Davies and Ryals, 2009, 2013). 
A well-designed team can help to improve the supplier's market performance and adaptability (Homburg et al., 2002), operational performance (Davies and Ryals, 2009), value creation (Bates and Bradford, 2009), new product development (Wießmeier et al., 2012), and customers' knowledge utilization (Salojärvi et al., 2010, 2013). The literature presents some elements that help to improve team performance: cross-functionality of the internal teams (Guenzi and Storbacka, 2015; Kotter and Schlesinger, 2008; Stock, 2006), well-designed training programmes (Baddar Al-Husan and Brennan, 2009; Marcos-Cuevas et al., 2014), existing job enlargement possibilities (Paiola et al., 2012), and the monitoring of team performance (Tzempelikos and Gounaris, 2015). To obtain such benefits a supplier should analyse the composition of these teams. Team composition requires paying attention to the profiles and skills of team members (Steward et al., 2010; Storbacka, 2012; Zupancic, 2008), including paying attention to proactivity, communication and conflict resolution skills (Atanasova and Senn, 2011). It is also necessary to check if a team is capable of advocating the change required by a KA (Gosselin and Bauwen, 2006), developing innovative solutions (Gosselin and Bauwen, 2006; Richards and Jones, 2009), improving competitive advantage in turbulent moments (Blocker et al., 2011) or introducing new ways of doing business (Salojärvi et al., 2013).

Improving buyer-supplier relationship quality embraces the development of interpersonal relationships and social bonds between the KA's professionals and the supplier's professionals (Abratt and Kelly, 2002; ALHussan et al., 2014; Blythe, 2002). These interpersonal relationships help to accelerate proposal approvals, mitigate problems and solve buyer-supplier conflicts (Haytko, 2004). To improve relationships KA managers and their teams should focus on the customer, and present professional integrity and trustworthiness (Abratt and Kelly, 2002; Guenzi et al., 2009; Nätti and Palo, 2012).

As shown above, the literature presents the importance of paying attention to KA managers and their teams. However, this literature does not show whether TMs get involved in performance improvement for KA managers and teams (including their roles on short-term orientation mitigation among KA managers). Even though they could be involved in such improvement the literature also does not present how they could do it. This conclusion will be used later to focus this research (see the Method's section). Table 1 presents a codification of the literature on KA managers and teams. 
Table 1 - KAM improvement based on managers and teams

\begin{tabular}{|c|c|}
\hline What to do regarding managers and teams & References \\
\hline $\begin{array}{l}\text { To check the KA managers communication and } \\
\text { persuasion power; the personal relationships established } \\
\text { by them; how they identify alternatives to satisfy the } \\
\text { KAs better; and how to mitigate the KA managers' } \\
\text { short-time orientation. }\end{array}$ & $\begin{array}{l}\text { Atanasova and Senn, 2011; Davies and } \\
\text { Ryals, 2009; Davies and Ryals, 2013; } \\
\text { Gounaris and Tzempelikos, 2014; } \\
\text { Guenzi et al., 2007; Pardo et al., 2014; } \\
\text { and Sharma, 2006. }\end{array}$ \\
\hline $\begin{array}{l}\text { To check the cross-functionality of the KA teams; the } \\
\text { training provided to these teams; the job enlargement } \\
\text { possibilities; the team performance; the teams' profile } \\
\text { and skills; and the team proactivity, communication and } \\
\text { conflict resolution skills. }\end{array}$ & $\begin{array}{l}\text { Atanasova and Senn, 2011; Baddar } \\
\text { Al-Husan and Brennan, 2009; Guenzi } \\
\text { and Storbacka, 2015; Kotter and } \\
\text { Schlesinger, 2008; Marcos-Cuevas et } \\
\text { al., 2014; Gebauer et al., 2013; Steward } \\
\text { et al., 2010; Stock, 2006; Storbacka, } \\
\text { 2012; Tzempelikos and Gounaris, } \\
\text { 2015; and Zupancic, 2008. }\end{array}$ \\
\hline $\begin{array}{l}\text { To check the profile and skills of the team members to } \\
\text { perform their action (which includes attention to the } \\
\text { proactivity, communication and conflict resolution } \\
\text { skills); to check the skills to develop innovative } \\
\text { solutions; to improve the competitive advantage in } \\
\text { rough moments, or to introduce new ways of doing } \\
\text { business. } \\
\text { To check if the teams can advocate the change required } \\
\text { by the key customer. }\end{array}$ & $\begin{array}{l}\text { Atanasova and Senn, 2011; Blocker et } \\
\text { al., 2011; Steward et al., 2010; } \\
\text { Storbacka, 2012; Zupancic, 2008; } \\
\text { Philippe Gosselin and André Bauwen, } \\
\text { 2006; Richards and Jones, 2009; and } \\
\text { Salojärvi et al., 2013. }\end{array}$ \\
\hline
\end{tabular}




\section{Culture, engagement and knowledge}

Culture, team engagement, and knowledge were also investigated in terms of KAM. The literature on culture focused on its benefits and methods of improvement. The benefits of team engagement and knowledge were also identified, as well as a requirement for knowledge improvement. These findings are presented below.

Culture embraces "a complex set of values, beliefs, assumptions, and symbols that define the way in which a firm conducts its business" (Barney, 1986, p. 657). The benefits provided by paying attention to culture were investigated. The findings indicate that internal culture can favour innovation, teamwork and customer orientation (Salojärvi et al., 2010; Storbacka, 2012; Zupancic, 2008), while a customer-centric culture helps to improve KAM (Davies and Ryals, 2009). Another study identified that paying attention to the cultural factors associated with the differentiation of sales/KAM could improve results/time orientation, customer orientation and operational alignment (Wilson and Woodburn, 2014). To improve culture a supplier should try to increase internal interaction and cooperation (Nätti and Palo, 2012), as well as analysing the cultural differences in global KAM (Atanasova and Senn, 2011; Ellis and Iwasaki, 2018; Neto et al., 2015). Internal cooperation can be leveraged by training, team rewards and recognition (Guenzi and Storbacka, 2015).

Suppliers should also try to engage all subordinates in responding to KA demands. As presented in the literature, esprit de corps is related to team commitment to their shared goals and to one other (Homburg et al., 2002; Richards and Jones, 2009). The findings indicate that paying attention to subordinates' commitment helps to assure KAM success (Workman et al., 2003) and to remove barriers to KAM (Guesalaga, 2014; Wilson and Woodburn, 2014). Other authors have identified that paying attention to esprit de corps helps to mitigate the internal conflicts that arise from power struggles between KAM units and internal networks (Guenzi and Storbacka, 2015; Leischnig et al., 2018) and to disseminate customer knowledge and the cross-functional capabilities of teams (Salojärvi et al., 2013). 
Given that knowledge is a fundamental success factor in KAM (Abratt and Kelly, 2002) suppliers should try to improve it. The findings indicate that knowledge helps to anticipate customers' plans and demands (Abratt and Kelly, 2002; Ryals and Rogers, 2007), to improve value creation (Shi et al., 2005), and to provide information that allows for analysis of the KA's value (Ryals and Rogers, 2007), as well as analysis of the risks or potential profitability (Piercy and Lane, 2006; Ryals and Holt, 2007). To improve knowledge TMs could check on the KAM formalization that favours the use of KA knowledge (Salojärvi et al., 2010), team-based structures (Salojärvi et al., 2013), and ways to improve KA knowledge acquisition, assimilation and use (Hakanen, 2014).

The literature on KAM emphasizes the importance of paying attention to culture, engagement and knowledge. However, this literature does not show whether TMs get involved with such topics. Even though they could be involved in such improvement the literature also does not present how this could be done. This conclusion will be used later to focus the research (see the Method's section). Table 2 presents a codification of the literature on culture, engagement and knowledge.

Table 2 - KAM improvement based on culture, engagement and Knowledge

\begin{tabular}{|l|l|}
\hline $\begin{array}{l}\text { What to do regarding Culture, Engagement, and } \\
\text { Knowledge }\end{array}$ & References \\
\hline $\begin{array}{l}\text { To promote a culture that favors internal cooperation } \\
\text { and the consideration of the cultural differences in the } \\
\text { global market. } \\
\text { To check the team rewards and recognition. }\end{array}$ & $\begin{array}{l}\text { Atanasova and Senn, 2011; Ellis and } \\
\text { Iwasaki, 2018; Guenzi and Storbacka, } \\
2015 ; \text { Nätti and Palo, 2012; and Neto } \\
\text { et al., 2015. }\end{array}$ \\
\hline $\begin{array}{l}\text { To check the KAs team commitment to the shared goals; } \\
\text { to mitigate the internal power struggles; to disseminate } \\
\text { the cross-functional capabilities of the team. }\end{array}$ & $\begin{array}{l}\text { Guenzi and Storbacka, 2015; Homburg } \\
\text { et al., 2002; Leischnig et al., 2018; } \\
\text { aichards and Jones, 2009; Salojärvi et }\end{array}$ \\
\hline $\begin{array}{l}\text { To check the KAM formalization, the team-based } \\
\text { structure, and the alternatives to improve KA's } \\
\text { knowledge acquisition, assimilation, and use. }\end{array}$ & $\begin{array}{l}\text { Hakanen, 2014; Salojärvi et al., 2010; } \\
\text { and Salojärvi et al., 2013. }\end{array}$ \\
\hline
\end{tabular}




\section{$\underline{\text { Organizational structure/conditions }}$}

The literature on organizational structure/conditions shows where to focus actions or how to promote changes. Details about these elements are presented below.

Paying attention to organizational structure is required in KAM (Birkinshaw et al., 2001; Ellis and Iwasaki, 2018; Millman and Wilson, 1999; Shi et al., 2010). Such attention aims to unveil opportunities to develop new services or to reduce costs and risks in KAM (Georges and Eggert, 2003) or to establish lateral relationships that help to promote continuous improvement (Haytko, 2004). To identify where to improve organizational structure a supplier could focus on the buyer-supplier dyad. This focus embraces the value created by a company's resources (Ivens and Pardo, 2008; MarcosCuevas et al., 2014). Beyond that, improvement of organizational structure requires an analysis of the organization's adaptability towards individual repeat customers (Rehme et al., 2013) and the misalignments that should be corrected in buyer-supplier relationships (Henneberg et al., 2009).

Improvement of organizational structure may also require an analysis of intra-organizational alignment (Guesalaga and Johnston, 2010; Marcos-Cuevas et al., 2014). This analysis embraces the partnerships already established by internal departments (Ivens et al., 2018; Piercy, 2009), as well as internal processes and procedures (Marcos-Cuevas et al., 2014; Pereira et al., 2018; Vanharanta et al., 2014). Beyond that a supplier may be interested in checking marketing and sales resources in relation to KA effectiveness (Workman et al., 2003) or considering whether the KAM perspective is fluid and flexible (Bradford et al., 2012).

Changes in internal conditions may also be required. To promote changes a supplier should mitigate the trade-offs that arise from conflict between short/long-term deliverables (Marcos-Cuevas et al., 2014), develop new key performance indicators (Guenzi and Storbacka, 2015), realign the goals and procedures of the different functional areas in the company (Doz and Kosonen, 2007; Guesalaga, 2014; Zupancic, 2008), and induce their KA managers to have a long-term perspective or develop joint actions with KAs (Salojärvi et al., 2010; Storbacka, 2012; Zupancic, 2008). Goal realignment may consider a combination of revenue value with the relationship value of the key accounts in the KAM decision-making process (Wang and Brennan, 2014). Beyond that a supplier could also search for continuous portfolio management in order to redirect investments to the most strategic accounts (Piercy and Lane, 2006) or to promote a structural redesign (Gounaris and Tzempelikos, 2014). 
According to the literature KAM requires paying attention to organizational structure/conditions. Despite the strategic importance of such a structure, however, the literature does not show if or how TMs get involved. This conclusion will be used later to focus this research (see the Method's section). Table 3 presents a codification of the literature on organizational structure/conditions.

Table 3 - KAM improvement based on organizational structure/conditions

\begin{tabular}{|c|c|}
\hline $\begin{array}{l}\text { What to do regarding Organizational } \\
\text { structure/conditions }\end{array}$ & References \\
\hline $\begin{array}{l}\text { To check the value created by the company's resources, } \\
\text { new services that could be offered, costs/risks that could } \\
\text { be reduced, the lateral relationships that could be } \\
\text { developed, the cooperation with the KAs, their } \\
\text { organization's adaptability toward individual repeat } \\
\text { customers, and the misalignments that should be } \\
\text { corrected. }\end{array}$ & $\begin{array}{l}\text { Georges and Eggert, 2003; Haytko, } \\
\text { 2004; Henneberg et al., 2009; Ivens } \\
\text { and Pardo, 2008; Marcos-Cuevas et al., } \\
\text { 2014; and Rehme et al., 2013. }\end{array}$ \\
\hline $\begin{array}{l}\text { To check the intra-organizational alignment on the } \\
\text { internal processes and procedures, on the internal } \\
\text { cooperation, and on new ways of doing business. }\end{array}$ & $\begin{array}{l}\text { Blocker et al., 2011; Bradford et al., } \\
\text { 2012; Guesalaga and Johnston, 2010; } \\
\text { Ivens et al., 2018; Marcos-Cuevas et } \\
\text { al., 2014; Pereira et al., 2018; Piercy, } \\
\text { 2009; Philippe Gosselin and André } \\
\text { Bauwen, 2006; Richards and Jones, } \\
\text { 2009; Salojärvi et al., 2013; } \\
\text { Vanharanta et al., 2014; and Workman } \\
\text { et al., 2003. }\end{array}$ \\
\hline $\begin{array}{l}\text { To mitigate the trade-offs that arise from the conflict } \\
\text { between short/long-term deliverables. } \\
\text { To develop new key performance indicators, goals and } \\
\text { procedures, joint actions with the KAs. } \\
\text { To combine revenue value with the relationship value of } \\
\text { the key accounts in the KAM decision-making process. } \\
\text { To redirect the investments to the most strategic } \\
\text { accounts or to promote a structural redesign. }\end{array}$ & $\begin{array}{l}\text { Doz and Kosonen, 2007; Gounaris and } \\
\text { Tzempelikos, 2014; Guesalaga, 2014; } \\
\text { Guenzi and Storbacka, 2015; Marcos- } \\
\text { Cuevas et al., 2014; Piercy, 2009; } \\
\text { Salojärvi et al., 2010; Storbacka, 2012; } \\
\text { Wang and Brennan, 2014; and } \\
\text { Zupancic, 2008. }\end{array}$ \\
\hline
\end{tabular}




\section{Customers and markets}

KAM also embraces paying attention to customers and markets. The previous studies on these elements present a requirement to define the KA list, the need to consider the benefits and challenges in the buyer-supplier relationship to improve the supplier's gain through KAs, the importance of business environment monitoring, and the requirements for monitoring, analysis and improvements in relationship quality. These elements are presented below.

Given that only a few customers will be classified as KAs a supplier must define which customers deserve to be kept on the list. This type of selection is usual in KAM (Tzempelikos and Gounaris, 2015) and classified as strategic for the supplier (Storbacka, 2012). According to the literature the selection and reselection of KAs aims to ensure long-lasting partnerships (Sullivan et al., 2012). The common elements usually considered include the customer's size, profitability and lifetime value (Baddar Al-Husan and Brennan, 2009; Toulan et al., 2006; Wengler et al., 2006), as well as the relational costs, revenue and technology matching (Ivens et al., 2018). Organizational or strategic fit are also considered in defining KAs (Georges and Eggert, 2003; Gosselin and Bauwen, 2006; Workman et al., 2003). This fit requires an analysis of shared investments (Davies and Ryals, 2014), the customer's market, demands and business model, and its alignment with the supplier's capabilities (Ryals and Rogers, 2007).

The benefits provided to KAs may help to improve the buyer-supplier relationship (Storbacka, 2012), improve the customer's satisfaction (Davies and Ryals, 2014; Guenzi et al., 2009; Scheer et al., 2010) or to induce the customer to get engaged in supplier projects (Davies and Ryals, 2014). Analysing benefits can unveil opportunities to increase the supplier's financial return (Gounaris and Tzempelikos, 2013), to improve account managers' performance (Guenzi et al., 2009) or to build barriers to competitors (Gounaris and Tzempelikos, 2014; Murphy and Li, 2015). Challenges verified in KAM were also investigated. These challenges include the need to improve the KA's business, and the promotion of mutual actions, commitment and trust (Abratt and Kelly, 2002; Jean et al., 2015). 
The results of business environment monitoring are mandatory in KAM (Wagner and Hansen, 2004). The literature refers to this monitoring as a KAM outside-in capability (Ivens et al., 2018) or as an operational capability (Wagner and Hansen, 2004). Such tracking aims to unveil opportunities to improve the value delivered to the customer (Helander and Möller, 2008; Sharma, 2006; Zupancic, 2008). Problems in the value offer can result in relationship disruptions (Friend and Johnson, 2014). By analysing the business environment and different value perspectives a supplier can manage its portfolio, plan its business, and define the value to be provided to the customer (Guenzi and Storbacka, 2015; Storbacka, 2012). The definition of this value should be proactive (Blocker et al., 2011; Flint et al., 2011) and consider both the customer and the supplier (Ivens and Pardo, 2008), as well as international specificities (Ellis and Iwasaki, 2018; Neto et al., 2015; Zupancic and Mullner, 2008). Paying attention to the different types of buyer-supplier alignment kinds is also mandatory (and may attract TMs' attention). The literature classifies these as opportunistic, passive, mutualistic and compensatory (Hsieh and Chou, 2011).

Analysis of the relationships established with KAs is required since long-term relationship intentions constitute a measure of KAM success (Guesalaga, 2014; Richards and Jones, 2009; Workman et al., 2003). This analysis may focus on the links between relationship quality and financial performance (Gounaris and Tzempelikos, 2013, 2014; Richards and Jones, 2009; Tzempelikos and Gounaris, 2013). Beyond that suppliers should also check that the KA is not trying to use its power to press the supplier (Ryals and Rogers, 2007). However, buyer-supplier differences seem not to constitute a problem. According to the literature stable buyer-supplier relationships can be established with KAs despite difference in their strategic interests (Ryals and Davies, 2013).

As presented in the literature, KAM needs to consider the buyer-supplier relationship and business environment monitoring. However, the literature does not show whether or how TMs get involved. This conclusion will be used later to focus this research (see the Method's section). Table 4 presents a codification of the literature on KAs and markets. 
Table 4 - KAM improvement based on KAs and markets

\begin{tabular}{|c|c|}
\hline What to do regarding KAs and Market & References \\
\hline $\begin{array}{l}\text { To define and refine the KA's list based on the analysis } \\
\text { of the customer's size, profitability, and lifetime value; } \\
\text { relational costs, revenue, and technology matching; } \\
\text { strategic elements; shared investments; and customer's } \\
\text { market, demands, and business model and its alignment } \\
\text { with the supplier's capabilities. }\end{array}$ & $\begin{array}{l}\text { Baddar Al-Husan and Brennan, 2009; } \\
\text { Davies and Ryals, 2014; Georges and } \\
\text { Eggert, 2003; Ivens et al., 2018; } \\
\text { Philippe Gosselin and André Bauwen, } \\
\text { 2006; Ryals and Rogers, 2007; Toulan } \\
\text { et al., 2006; Wengler et al., 2006; and } \\
\text { Workman et al., 2003. }\end{array}$ \\
\hline $\begin{array}{l}\text { To check the value added to the KAs to induce the } \\
\text { customer to get engaged in suppliers' projects; to unveil } \\
\text { opportunities to increase the supplier's financial return, } \\
\text { to improve the account managers' performance, or to } \\
\text { build barriers to the competitors. }\end{array}$ & $\begin{array}{l}\text { Davies and Ryals, 2014; Gounaris and } \\
\text { Tzempelikos, 2013; Gounaris and } \\
\text { Tzempelikos, 2014; Guenzi et al., } \\
\text { 2009; Murphy and Li, 2015; } \\
\text { Storbacka, 2012. }\end{array}$ \\
\hline $\begin{array}{l}\text { To check if the business environment monitoring is } \\
\text { proactive and consider both the customer's and the } \\
\text { supplier's, as well as the international specificities. }\end{array}$ & $\begin{array}{l}\text { Blocker et al., 2011; Ellis and Iwasaki, } \\
\text { 2018; Flint et al., 2011; Ivens and } \\
\text { Pardo, 2008; Jean et al., 2015; Neto et } \\
\text { al., 2015; and Zupancic, 2008. }\end{array}$ \\
\hline $\begin{array}{l}\text { To check if the buyer-supplier alignment is } \\
\text { opportunistic, passive, mutualistic, or compensatory; } \\
\text { and if the relationship with the KA is stable despite the } \\
\text { difference in the strategic interests. }\end{array}$ & $\begin{array}{l}\text { Hsieh and Chou, 2011; and Ryals and } \\
\text { Davies, } 2013 .\end{array}$ \\
\hline $\begin{array}{l}\text { To improve the links between relationship quality and } \\
\text { financial performance; and the companies value } \\
\text { proposition (which embraces price, customer service, } \\
\text { product/service adaptation, and logistic adaptation). To } \\
\text { mitigate the KAs power - which can be pressing the } \\
\text { supplier. }\end{array}$ & $\begin{array}{l}\text { Gounaris and Tzempelikos, 2013; } \\
\text { Gounaris and Tzempelikos, 2014; } \\
\text { Guesalaga, 2014; Ivens et al., 2018; } \\
\text { Richards and Jones, 2009; Ryals and } \\
\text { Rogers, 2007; Tzempelikos and } \\
\text { Gounaris, 2013; and Workman et al., } \\
2003 \text {. }\end{array}$ \\
\hline
\end{tabular}

Figure 1 presents possible focuses on KAM improvement. 
Figure 1 - Possible focuses on KAM improvement

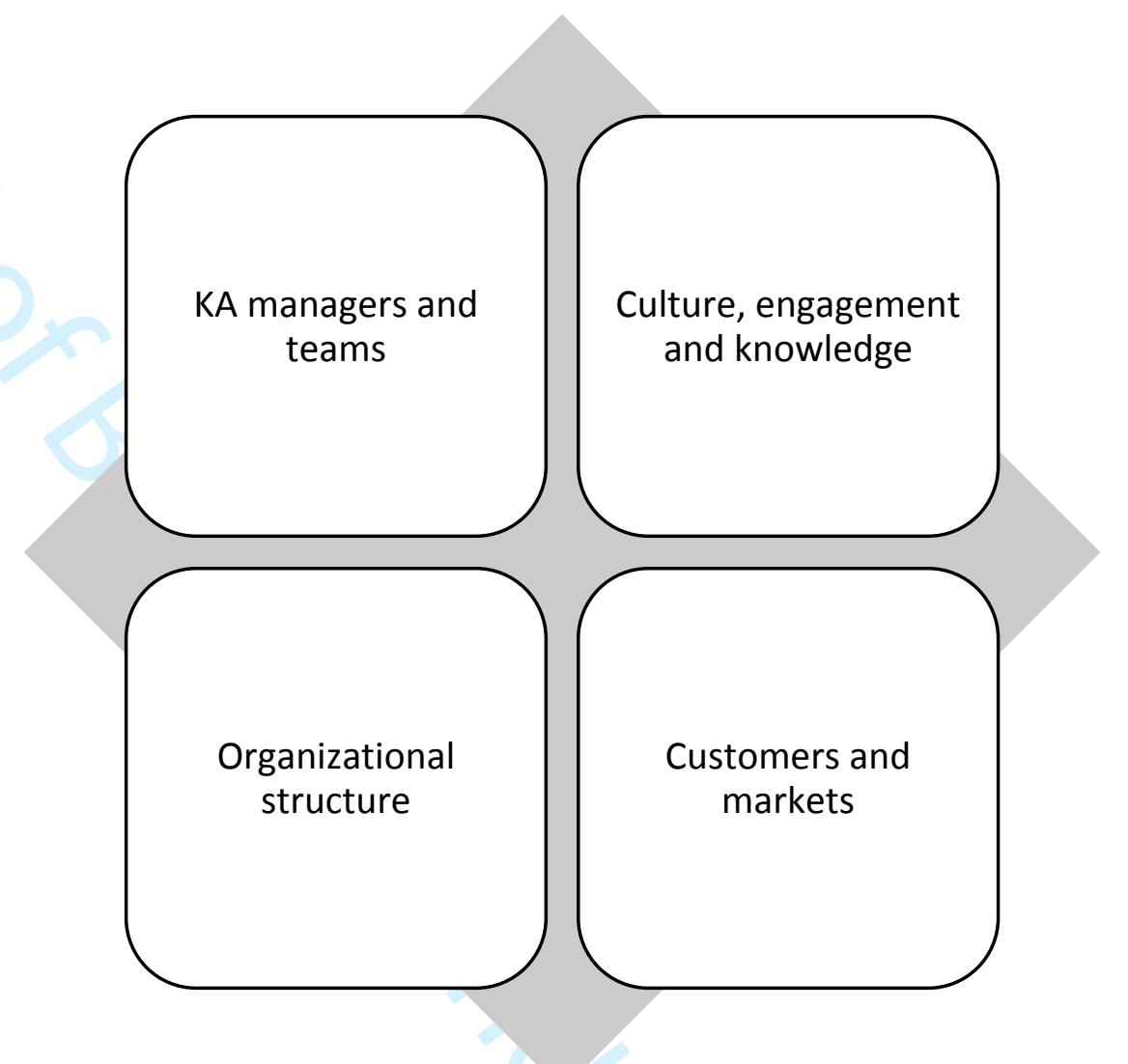




\section{METHOD}

\section{$\underline{3.1 \text { Research design }}$}

This study adopted a qualitative approach given the research focus on the role of TM, which is multifaceted and context bound. According to the literature qualitative case studies are recommended when a study aims to develop and offer detailed insights and unveil complexity reflecting both organizational and individual processes (Eisenhardt and Graebner, 2007; Miles and Huberman, 2004; Yin, 2009). This approach is especially appropriate since the TM role constitutes an under-researched topic. The option for multiple case studies aims to select information-rich cases (Patton, 2002). Based on the literature review a codification approach to analysing qualitative text (Saldaña, 2015) and grounded-theory (Corbin and Strauss, 1990) was used. No specific tool was adopted other than a logical codification of nouns and adjectives found in peer-reviewed studies. The codification of the previous literature unveiled the following actions that could attract TM attention: KA managers and teams, culture, engagement and knowledge, organizational structure/conditions, and KAs and markets. Tables 1, 2, 3 and 4 summarize the possible actions identified. These actions were used to define the open-ended questions (see Appendix 1).

\subsection{Data collection}

Activities associated with the data collection started by defining the profile of the companies to be investigated. The researchers defined that these companies should have from 100 to 999 employees, and annual revenues should range from US\$ 50 million to US\$ 1 billion. These elements are usually observed in midsized companies (Gartner Group, 2015). The focus on midsized companies considered the importance of such organizations to the global industrial scenario. These companies also had to operate in two of the following continents: America, Europe and Asia. This criterion aimed to select companies operating in some of the most competitive markets around the globe.

The selection of midsized companies that met these conditions encompassed several stages. In the first stage the researchers visited the chemical, electronic, automotive and equipment industries' associations with the aim of identifying their biggest affiliates. In these visits the researchers initially presented the project. After that they asked for a list of the associations' affiliates that presented the highest annual revenues. The focus on these big companies encompassed the following assumption: a big buyer may be listed among the KAs of several midsized suppliers. At this stage it was possible to identify 40 big buyers. 
In the second stage the researchers asked the industrial associations' managers to introduce the researchers to the general purchasing manager of each big company indicated by the association. Over three months the researchers contacted 40 general purchasing managers. Twelve of them returned the researchers' calls, and seven of them agreed to provide a list of their preferred midsized suppliers. The list provided by all purchasing managers had 93 midsized suppliers.

In the third stage the general purchasing managers of the big companies were asked to introduce the researchers to the top managers of their best midsized suppliers. Aiming to help the purchasing managers, the researchers provided a project summary and a draft of an e-mail message. After two weeks twenty-five top managers of midsized companies had agreed to participate in the research.

In the fourth stage these twenty-five top managers were asked to say something about the KAM programmes of their companies. Four of them declared that their companies did not have a KAM programme. Another group of nine top managers informed us that their companies did not have enough experience with the topic. These thirteen companies were removed from the companies selected for the study. In the end twelve top managers of the midsized suppliers indicated by the big buyers were deemed suitable for inclusion in the investigation. This process allowed the selection of knowledgeable top managers of midsized companies, thus enriching the findings. The twelve cases selected helped to unveil the actions performed by TMs when managing their KAs (see the TMs profile in Table 5). This number of cases is slightly higher than the range of suitable ones indicated in the literature, which is 6 -10 (Yin, 2009).

Table 5 - TMs interviewed

\begin{tabular}{|c|c|c|c|c|c|c|}
\hline $\begin{array}{l}\text { Top } \\
\text { manager }\end{array}$ & $\begin{array}{l}\text { Time in the } \\
\text { current role } \\
\text { (years) }\end{array}$ & Age & Gender & $\begin{array}{c}\text { Company } \\
\text { headquarter }\end{array}$ & Industry & Employees \\
\hline 1 & 9 & 54 & $\mathrm{M}$ & $\mathrm{UK}$ & Electronic & 920 \\
\hline 2 & 12 & 46 & $\mathrm{M}$ & UK & Chemical & 830 \\
\hline 3 & 7 & 51 & $\mathrm{M}$ & SWEDEN & Equipment & 790 \\
\hline 4 & 18 & 59 & $\mathrm{M}$ & SPAIN & Chemical & 910 \\
\hline 5 & 10 & 47 & $\mathrm{~F}$ & USA & Chemical & 750 \\
\hline 6 & 16 & 50 & $\mathrm{M}$ & USA & Electronic & 890 \\
\hline 7 & 9 & 46 & $\mathrm{M}$ & USA & Equipment & 650 \\
\hline 8 & 21 & 51 & $\mathrm{M}$ & GERMANY & Electronic & 910 \\
\hline 9 & 18 & 57 & $\mathrm{M}$ & GERMANY & Equipment & 930 \\
\hline 10 & 13 & 49 & $\mathrm{M}$ & ITALY & Chemical & 770 \\
\hline 11 & 13 & 48 & $\mathrm{~F}$ & FRANCE & Chemical & 900 \\
\hline 12 & 14 & 53 & $\mathrm{M}$ & SOUTH KOREA & Equipment & 810 \\
\hline
\end{tabular}


Three interviews with companies 1, 2 and 3 were applied to test the research protocol (pilot study). The top managers of these companies were questioned about the research at the end of their interviews. The three interviewees offered small suggestions to break the ice during the meetings, as well as to capture a more detailed picture of top managers' role in KAM. Suggestions for improving the way a topic was approached and discussing the answers provided were also collected.

In the following interviews we tried to explore the elements that were identified in the previous interviews. All meetings were finished when two conditions were met: all research protocols were applied, and no new evidence was emerging from the interviewee (Corbin and Strauss, 2007). Since we were not allowed to tape the interview sessions we had to take notes. These notes were later transferred to a text editor (Word), resulting in 192 pages.

In all the interviews the collection of data encompassed open-ended questions, as well as documental analysis. The meetings were scheduled by e-mail and carried out through Skype. Four top managers established three conditions in advance: anonymity, no taping, and a time limit for the interview (around 45 minutes). All meetings were scheduled for the top managers' lunch breaks (all interviewees seemed to be in their offices at this time) and lasted more than 70 minutes (the longest interview lasted 90 minutes). At least two researchers attended all interviews. This condition aimed to improve the data collected. At the end of the interviews we always asked the interviewees for documents about the topics discussed. Six managers sent us at least one electronic document. These documents presented KA managers' reports on opportunities prospection. Findings extracted from public electronic documents were also considered, thus allowing some triangulation between interviews and documents. Table 6 presents the documents collected. 


\section{Table 6 - Documents collected}

\begin{tabular}{|l|l|}
\hline Source & Documents \\
\hline TM2 & $\begin{array}{l}\text { Meeting minutes with anonymous customers. } \\
\text { Specifications initially required by the customer and the ones delivered by } \\
\text { the manufacturer after the changes were negotiated. }\end{array}$ \\
\hline TM4 & $\begin{array}{l}\text { Meeting minutes with anonymous customers. } \\
\text { Members profile of the mixed teams. }\end{array}$ \\
\hline TM6 & $\begin{array}{l}\text { Meeting minutes with anonymous customers. } \\
\text { Specifications initially required by the customer and the ones delivered by } \\
\text { the manufacturer after the changes were negotiated. }\end{array}$ \\
\hline TM8 & $\begin{array}{l}\text { Internal reports presenting product design improvements. } \\
\text { Members profile of the mixed teams. }\end{array}$ \\
\hline TM9 & Members profile of the mixed teams. \\
\hline TM12 & $\begin{array}{l}\text { Internal and anonymous report on profit increase after the requirements } \\
\text { negotiation with the customer. }\end{array}$ \\
\hline Companies' web pages & $\begin{array}{l}\text { Internal reports on value-added not provided by the competitors (9 } \\
\text { companies), sales increase (12 companies), and list of the KAs (7 } \\
\text { companies). }\end{array}$ \\
\hline $\begin{array}{l}\text { Web pages of magazines } \\
\text { or industrial associations. }\end{array}$ & $\begin{array}{l}\text { New deals closed by the manufacturer due to a value-added not provided by } \\
\text { the competitors (12 companies). } \\
\text { Details of long-term contracts closed with big customers (7 companies). }\end{array}$ \\
\hline
\end{tabular}

After the data collection the researchers wrote their report (collected data were coded based on grounded theory coding). The researchers' reports were then crosschecked in a research team meeting. The crosschecked reports were sent to the interviewees for validation. After two months no single return was received by the researchers. A new e-mail was sent to the top managers requesting a second Skype conversation. New contacts were realized with all the interviewees. In the second round of interviews the managers seemed to be more relaxed (all of them were in a hotel or at home, instead of in their offices). This relaxation helped to create an open atmosphere, thus facilitating the conversations about the report. Four top managers suggested minor changes in our reports. No single Skype contact lasted less than 60 minutes (some contacts lasted for 100 minutes). All top managers used part of this time to ask the researchers about the findings collected by the other managers - the analysis of this data induced some of the TMs to provide new information. As a result some new and interesting information was collected during these conversations, thus helping us to improve our findings reports. 


\section{$\underline{3.3}$ Trustworthiness, credibility and reliability}

Experts revised the study with the aim of allowing future replications (Eisenhardt, 1989). A set of criteria were used to assure trustworthiness, credibility and reliability. These criteria encompass fit, understanding, generality, control (Corbin and Strauss, 2007), transferability, dependability, confirmability and integrity (Corbin and Strauss, 2007; Hirschman, 1986; Wallendorf and Belk, 1989). Fit was observed in the selection of companies. Understanding encompassed the presentation of findings to the interviewees. Generalization encompassed the selection of TMs working for companies with similar sizes and customers. Control encompassed the conclusion validation by the participants. Transferability encompassed the selection of TMs working for the best midsized suppliers with several years of experience with global KAM programmes. Dependability encompassed the focus on the best midsize suppliers (according to the buyers). Conformability embraced the individual analysis of each case (which was always executed a few days after the interview, e.g., 2-3 days) and included all evidence related to the actions performed by each TM interviewed. After analysing all the cases individually a cross-case analysis was performed. These analyses aimed at identifying similarities and differences among the TMs interviewed, as well as the reasons for these similarities/differences. In both analyses the findings were coded with the intention of confronting them with elements extracted from the literature. This codification was based on grounded theory (Corbin and Strauss, 1990; Strauss and Corbin, 1998). The revised document was presented to the interviewees. Integrity encompassed anonymity and ethical standards. 


\section{FINDINGS}

The findings indicate that the TMs perform four different groups of actions when managing their KAs. These activities were grouped into KA managers and their teams, culture, team engagement and knowledge, organizational structure/conditions, and customers and markets. No significant differences among the respondents were identified (considering their gender, experience, industry or other criteria). However, some of the actions identified seem to present a certain overlap with those that should be performed by KA managers. This perception is endorsed by all of the TMs investigated. As identified, this overlap helps them to take better decisions. Beyond that, this overlap also helps TMs to evaluate KA managers' actions and decisions. Nevertheless, the TMs also recognize that their activities are similar but their dedication is different. While a KA manager spends $100 \%$ of the time managing his/her KA, a TM spends only a small portion of his/her time in such actions (since they have other functions to perform).

"To meet your targets, you must have minimum contact with the day-to-day of your company. In such contacts, you cannot perform their subordinates' tasks but inspire, check and improve their actions and decisions " (TM1).

Details of the TMs' role in each group of actions presented in the literature are presented below.

\section{$\underline{\text { KA managers and teams }}$}

The TMs seem to be interested in evaluating/improving KA managers' performance or in identifying emerging talents among the professionals who work for their companies. To do this the TMs check the information gathered by these professionals. The first evaluation focuses on the market. As ascertained, the information gathered by KA managers is always presented in written reports. The documents collected indicate the requirements of quality, delivery performance and services (which confirms the information gathered from the interviews). Even with access to the reports, though, the TMs keep asking KA managers for news.

\footnotetext{
"I show the KA managers what I want to know from them" (TM10).

"To help them to perform a better job, you have to induce them to talk about their challenges" (TM5).
} 
The TMs also ask other people who work for their companies (e.g., salespeople and technicians) to prospect for the same information with their contacts in the KA's organization (technicians, buyers and managers). In informal (and sometimes private) contacts they ask them for such information. The TMs use this information to further evaluate the KA managers' performance or to identify emerging talents among the professionals who work for their companies.

\section{"Whenever I can, I ask all of them about the news" (TM12).}

"I use this information to evaluate the KA's managers or to dig [up/for] new talents" (TM1).

Beyond paying attention to the KA managers and their teams, the TMs also pay attention to the culture, engagement and knowledge of their subordinates. Details of this attention are presented below.

\section{Culture, engagement and knowledge}

According to one interviewed TM interviewed permanent questioning helps to create an internal culture that favours the prospection and analysis of valuable information. This culture also helps to improve the engagement of all persons working for their companies (since they feel empowered by the TM, which helps to reduce their anxiety). To leverage this engagement the TMs demonstrate their interest in all valuable information provided.

"To create a culture I show to my subordinates what I want to know from them" (TM10).

"I show them that valuable information constitutes the best way to catch my attention" (TM5).

However, the TMs seem to be very sceptical about the information gathered. As identified, they secretly try to check this information. To do so the TMs access other external sources (e.g., KA top managers). This practice aims to improve the company's knowledge. The TMs also prospect for information with other top executives in their industrial associations or the KA's organization.

"You cannot believe in a single source of information" (TM9).

"Some information will only be released by the customer's top manager. Moreover, this information is only released to the supplier's TM. So, you have to go there to gather this information" (TM 3). 
Once the TMs have made their decisions they try to persuade their KA managers about the validity of these decisions. This persuasion aims to keep the KA managers and their subordinates engaged with KAM. So, if the development of an innovative solution is approved the TMs state that this sort of product can be less sensitive to a price war that could be orchestrated by competitors, or that this product can increase profit margins or market share, or quickly unveil new business opportunities. If the development of a less innovative solution is the option selected by the TM they state that this option will help to maintain the previously conquered markets or to confront competitors that offer a lower price. When the opportunity is left for competitors the TMs argue that the solution would not have a good cost/benefit relationship or that the company could face strong attacks from competition in the near future. This persuasion is performed after actions associated with the customer and markets have been performed. These actions are presented in the next subsection.

\section{"If you want to engage your strategic managers you have to tell them about the elements} that guided your decision" (TM12).

After persuading, the TMs ask their KA managers to disseminate the new valuable knowledge in their organization. This dissemination will help to define technical requirements to be included in the project, elements to be observed in a new business proposal (including the best combination of price and value added) or the terms to be included in the new contracts.

"The information dissemination helps to subsidize the future actions to be developed at different company levels" (TM8).

The TMs' paying of attention to the organizational structure/conditions of their companies was also identified. This is presented below. 


\section{$\underline{\text { Organizational structure/conditions }}$}

Regarding organizational structure/conditions, the TMs seem to be interested in understanding what could be changed, why it should be changed or how to change it. To improve their understanding of these topics the TMs indirectly get involved with analysing how changes required by key customers will affect their companies. A lack of time or specific knowledge seems to justify such an approach. As identified, an indirect style encompasses the promotion of internal debates on the changes that should be promoted to meet the requirements presented by the KA (which include organizational structure/conditions). To improve these debates the TMs induce the team members to question conclusions' validity regarding changes required. The conclusions of such dialogues may indicate the need to develop a new solution, to change the product specifications, to redesign the facilities, to modify the manufacturing process or to improve customer service. They also unveil the time and costs to be incurred.

"To assure the best results you should manage the KA's demand analysis without getting involved in it" (TM7).

"I like to question some team members (in private) about their opinion regarding the change proposed by another person/group or about the implications of such change. In public I stimulate them to express their opinions. It works fine” (TM2).

Part of the conclusions of the previous analyses is submitted to an external debate. To incentive this external debate the TMs ask for unexpected meetings with customers and partners. These debates aim to unveil opportunities to improve the team's conclusions (including the product designers' conclusions). The lessons learned in these sessions help to identify how the KA or service partners evaluate the strengths and weaknesses of the possible solution. They also help to determine how the KA evaluates its competitors. As ascertained, the information gathered in external debates also constitutes a good source of ideas to reduce costs or to improve a product.

"I like to ask for premature presentations to the customer or service partners. My subordinates hate this approach but the information gathered in such moments helps to improve our offer" (TM2).

"The draft project presentation helps to improve the solution to be implemented or to unveil some details to be explored in our next commercial proposal" (TM3). 
The TMs' paying of attention to customers and markets constitutes another group of actions performed by the TMs interviewed. Details of this attention are presented below.

\section{$\underline{\text { Customers and markets }}$}

The TMs' organizations can face some barriers when approaching a KA. These barriers are usually associated with problems verified in the buyer-supplier relationship (delays to deliveries or technical issues presented by products sourced by the manufacturer). Aiming to mitigate past problems, the TMs try to keep in close contact with the KA's top manager. In these contacts the TMs try to identify how the KA's top manager perceives the existing supply options, and how it would be possible to mitigate problems that have occurred.

“A manufacturer's top manager is the best person to prospect trends with the KA's top manager" (TM3).

"You must visit the top manager of your customer to solve some problems" (TM6).

The TMs also focus on changes that could be made by KAs. To do this they look for ways to change technical requirements, target prices or specified contractual terms. To induce changes in the conditions the TMs ask KA managers to help the KA to improve its project. This involvement aims to unveil ways to change some of the KA's demands. To remove the barriers to the changes the manufacturer's TM also gets in touch with the KA's top manager. In these contacts the manufacturer's TMs reinforce the benefits previously provided to the KA (from purchase to final disposal of the product). Afterwards they present the mutual advantages of a particular change not considered by the KA.

"The customers always ask for more than they already want to have" (TM11).

"If you want to induce a change, you have to reinforce your strengths to the KA's top manager" (TM9).

External changes may also include banks and governmental agencies. With bank the TMs try to obtain more affordable financing for the KAs (but this is only done after their staff declare that the bank will not change its requirements). By mapping governmental agencies the TMs try to influence these agencies to create new public incentives or tax exemptions for the solutions under development or the use of a specific technology. The TMs seem to have patience when trying to change.

"My staff talk to the bank staff. I must talk to the bank director to get a better credit offer to the KA" (TM4). 
"I try to connect our new solutions to the public incentives or tax exemptions (ex.: sustainable products, products that can be exported or that use local components)" (TM8).

Only after trying to change conditions do the TMs decide whether or not to approve meeting KA demands. To do this the TMs initially analyse the KA's manager report. This report indicates the attractiveness of the KA's demand (after the changes negotiation). An opportunity is classified as "unattractive" if the KA is facing (or may face) cash problems, if the opportunity requires enormous changes to the product for a low price, or if the customer is demanding uninteresting improvements. This analysis must be combined with a study of their own company's reality (which is provided by other areas). The analysis of their internal reality helps to define the number of KAs that their companies should have. Since the companies investigated have more than one KA manager the TMs also check the reality of the other KAs. Beyond that, they check their company's targets: revenue, profits, market penetration, company image and the resources available. The results of the previous analyses indicate whether a customer will be included or excluded from the KA's list.

"In some cases, is better to leave an unattractive opportunity to your competitors. However, you should do it wisely" (TM5).

“Changes in the KA's list help to improve your company's return. So, you cannot hesitate to do it" (TM10).

When KA demands will not be met the TMs discuss with the KA manager how they plan to implement this decision in practice. Particular attention is dedicated to opportunities that will be redirected to competitors. Offering a high price constitutes the best way to leave the chance to competitors without damaging the relationship.

"I ask my KA manager to increase prices to induce the customer to revise its demands again or to buy from my competitors" (TM4). 
In other cases, a higher price induces the customer to revise its requirements. However, not all demands that are changed by the KA will be classified as "attractive". In such cases, the challenge is to reject the order. To help the KA's manager to succeed in such a challenge the TMs try to persuade the KA's top manager to redirect the order to another supplier. To do this they inform the KA's top manager that this deal cannot be closed for a lower price. The objective here is to lose the "unattractive" contract politely.

"To reject an unattractive opportunity and keep a good relationship with a KA I call the KA's top manager and tell him/her that we reached our limit. After that I leave the scene for a while" (TM11).

When the opportunity is attractive the TMs can approve or even change a price that has been suggested by the KA manager. To accept or change the amount the TMs check the strengths and weaknesses of the company with those of its competitors. This analysis has been previously performed by the manager responsible for the KA and considers the technical problems faced by their company and its competitors in the past.

"I am responsible for defining the best price after all calculations were finished. This price must be profitable to us and attractive to the KA" (TM2).

For attractive opportunities the TMs also think that a price war may be orchestrated by the competitors. To mitigate a price war over an attractive opportunity or to justify a higher price the TMs try to persuade the KA's top manager not to accept a competitor's offer. This persuasion focuses on the competitor's weaknesses. This action seems to be a final game played by the TMs.

"You must use all you have to win the order" (TM3).

"As TM I try to convince the KA's top manager that my company has the best offer (considering the cost-risk-benefit)" (TM1).

Table 7 presents a summary of the findings. 
Table 7 - TMs' role in KAM

\begin{tabular}{|l|l|}
\hline Code & Summary of findings \\
\hline KA managers and & $\begin{array}{l}\text { Use every small personal contact to collect information associated with the } \\
\text { KA. }\end{array}$ \\
\hline $\begin{array}{l}\text { Culture, engagement } \\
\text { and knowledge }\end{array}$ & $\begin{array}{l}\text { Get involved in the creation of an internal culture that favours the } \\
\text { prospection and analysis of valuable information. } \\
\text { To create the desired culture the TMs demonstrate their interest in all } \\
\text { valuable information gathered by all hierarchical levels of their companies, } \\
\text { are sceptical and induce the dissemination of the information that they have } \\
\text { already checked. } \\
\text { Persuade KA managers that the decision taken was the "best option" to } \\
\text { remove internal resistances. }\end{array}$ \\
\hline $\begin{array}{l}\text { Organizational } \\
\text { structure/conditions }\end{array}$ & $\begin{array}{l}\text { Induce the internal and external questioning of the validity of changes } \\
\text { proposed. }\end{array}$ \\
\hline KAs and markets & $\begin{array}{l}\text { Contact the KA's top manager to identify how he/she perceives the existing } \\
\text { supply options, and how it would be possible to mitigate the problems } \\
\text { occurred. } \\
\text { Use the mutual benefits provided by their companies and competitors' } \\
\text { weaknesses to persuade the KA's top manager to change some requirements } \\
\text { or to accept a higher price. } \\
\text { Try to induce governmental agencies or banks to change their requirements } \\
\text { in order to increase the KA's attractiveness. } \\
\text { Get engaged in the final decision about whether the customer will be kept in } \\
\text { the KA's list (or not) - based on their own company's situation and the } \\
\text { customer's situation/offer. } \\
\text { Discuss with the KA manager how to redirect an unattractive opportunity to } \\
\text { competitors without damaging the relationship. } \\
\text { Persuade the KA's top manager to redirect the order to another supplier when } \\
\text { this order is unattractive (without damaging the relationship). } \\
\text { Try to improve gains in attractive orders (including KA top manager } \\
\text { persuasion). }\end{array}$ \\
\hline
\end{tabular}




\section{DISCUSSION AND CONCLUSION}

The findings indicate that the TM role includes actions associated with KA managers and teams, culture, engagement and knowledge, organizational structure/conditions, and KAs and markets (see Table 7). This section discusses research contributions, managerial implications, limitations and future research.

\section{$\underline{\text { Research contribution }}$}

The findings indicate that TMs use every small personal contact to collect additional information associated with a KA. This conclusion contributes by indicating how TMs secretly improve their understanding of the profile and skills of their company's teams (Steward et al., 2010; Storbacka, 2012; Zupancic, 2008), of the quality of the personal relationships established by KA managers (Gounaris and Tzempelikos, 2014; Sharma, 2006), or of KA demands presented by KA managers (Gosselin and Bauwen, 2006). Improvements to the understanding of KA demands help TMs to better evaluate innovative solutions that could be developed (Gosselin and Bauwen, 2006; Richards and Jones, 2009) or ways to improve their companies' competitive advantage in turbulent moments (Blocker et al., 2011).

TMs seem to be very sceptical. This scepticism induces them to check information through other external sources (e.g., KA top managers or other top executives in the industrial associations) and to present this information internally. This finding contributes by indicating that checks and presentation are used by TMs to create an internal culture that favours customer orientation (Salojärvi et al., 2010; Storbacka, 2012; Zupancic, 2008), as well as improving fit with customers (Harrison and Kjellberg, 2010; Preikschas et al., 2017; Pressey et al., 2007). TMs also try to improve internal engagement by inducing team members to disseminate information that TMs have considered "valuable." This dissemination is executed by KA managers (who have better access to the lower hierarchical levels). This finding contributes by indicating how TMs create better conditions for the use of customer knowledge (Hakanen, 2014). 
TMs also try to persuade KA managers that a made decision is the "best option". To do this TMs present the elements that have guided their choices to KA managers and other managers that work for their companies. This finding contributes by indicating what TMs do to improve the future activities of managers (Davies and Ryals, 2013; Salojärvi et al., 2010), to remove internal resistance to KA new demands or projects (Guesalaga, 2014; Marcos-Cuevas et al., 2014; Pressey et al., 2014; Wilson and Woodburn, 2014), or to mitigate the short-term orientation presented by some KA managers (Davies and Ryals, 2013).

TMs ask their managers to organize cross-functional teams to analyse "what should be done to meet the KA's demands". This finding contributes by indicating how TMs indirectly influence team composition in order to improve the utilization of the customer knowledge (Salojärvi et al., 2010, 2013). The positive influence on team effectiveness of members with different expertise and profiles is presented in the literature (Stock, 2006), as well as the contribution of cross-functional teams to KAM success (Guenzi and Storbacka, 2015). The findings also contribute by indicating how TMs stimulate the prospection of external opinions when evaluating solutions proposed by an internal team (Ivens et al., 2009). To stimulate this prospection TMs ask their KA managers to promote unexpected meetings with customers and partners (with or without the presence of the TM). Other contacts are organized by sales team (Balboni and Terho, 2016). External questioning can even include the customers of the KA (Thomas, 2016). The findings also contribute by indicating that the internal and external discussions promoted by the TMs help to improve the value delivered to the KA (Sharma, 2006; Zupancic, 2008).

The findings contribute by indicating that close contact with a KA's top manager helps TMs to mitigate past problems in the buyer-supplier relationship (Brehmer and Rehme, 2009; Guenzi et al., 2007; Guesalaga, 2014), as well as to identify how the KA's top manager perceives the existing supply options. Such actions also help to improve the supplier's knowledge of topics that customers do not usually inform KA managers about. This finding contributes by indicating a new way to improve supplier knowledge, thus helping to ensure successful KAM (Abratt and Kelly, 2002), to anticipate customers' plans and demands (Abratt and Kelly, 2002; Ryals and Rogers, 2007), and to improve value creation (Shi et al., 2005). 
The persuasion of KA top managers aims to induce them to change some of their requirements, which seems to reduce the chances of future problems in the buyer-supplier relationship. This finding contributes by indicating how TMs try to mitigate differences in companies' objectives (Corsaro and Snehota, 2011; Murfield and Esper, 2016) or a better offer presented by another supplier (Pick and Eisend, 2014). Actions developed to change requirements imposed by governmental agencies or banks focus on the higher hierarchical levels of the government or banks. This conclusion contributes by indicating a new method used by TMs to improve the KA's attractiveness (Mortensen, 2012; Ritter and Andersen, 2014; Rocca et al., 2012).

TM engagement in KA list refinement is in line with the literature (Boejgaard and Ellegaard, 2010; Powers and Sterling, 2008; Simkin, 2008). For the TMs interviewed the KA list constitutes a moving target (Blocker and Flint, 2007), since companies have to consider their objectives in such moments (Corsaro and Snehota, 2011). The findings also indicate that the TMs refine this list considering the KA's situation and the implications of KA demands for the supplier's revenue, profits, market penetration or image. These conclusions contribute by unveiling other elements that can induce a supplier to change its position (Crosno et al., 2015) and how a supplier reacts when a KA tries to use its power to press it (Ryals and Rogers, 2007).

TMs also discuss with KA managers how to redirect an unattractive opportunity to competitors without damaging the relationship. As ascertained, they define a higher price for the product or service, thus aiming to induce the KA to buy from competitors or to revise some points of its original demand. Beyond that, TMs try to persuade KA top managers to redirect orders to another supplier when orders are unattractive. These findings contribute by indicating how TMs try to ensure long-lasting partnerships (Sullivan et al., 2012), to improve the organizational or strategic fit (Georges and Eggert, 2003; Gosselin and Bauwen, 2006; Workman et al., 2003), to increase the supplier's financial return (Gounaris and Tzempelikos, 2013), or to improve account managers' performance (Guenzi et al., 2009). 
TMs can increase the prices suggested by KA managers even when they want to win an attractive order. This conclusion suggests that, for the TMs interviewed, KAM seems to embrace much more than "better relationship management" (Spencer, 1999). This conclusion contributes by indicating how TMs try to improve their companies' financial return, thus promoting a positive impact on their companies (Gounaris and Tzempelikos, 2013; Sarkees, 2011). Before increasing prices TMs check their competitors' situation or the chances of a price war being promoted by these competitors. After that, TMs try to persuade KA top managers to accept higher prices. To do this they present the competitors' weaknesses. However, prices can also be reduced (Henke et al., 2008). These findings contribute by indicating what TMs do to build barriers to competitors (Gounaris and Tzempelikos, 2014; Murphy and Li, 2015).

This study contributes to the KAM literature in several ways. First, the study adds to our understanding of the role of TMs in KAM. The KAM literature has recognized the important role of TMs in the successful implementation of KAM programmes but, apart from a few exceptions (e.g. Tzempelikos, 2015; Guesalaga, 2014), there has been little detailed analysis of the specific ways in which TMs are involved in KAM and the organizational implications. The present study explores the involvement of TMs in KAM functioning, not merely as participants in decision-making, and identifies key areas, both organization-focused and market-focused, where TMs influence KAM success. Thus, the study helps to provide a holistic view of the role of top management in KAM. In addition, the study further develops the theoretical basis of KAM as an organizational context factor rather than just a sales management practice where decisions are determined within the boundaries of the sales department. KAM is an organizational level strategy that touches upon various aspects of a firm such as sales efforts, culture, structure and positioning in the marketplace. The study shows that TMs play a key role in coordinating KAM influences on these areas and in ensuring the organizational support that the KAM function requires.

Second, the study attempts to synthesize (a) key account managers and teams, (b) culture, engagement and knowledge, (c) organizational structure/conditions, and (d) customers and markets. This is designed to form a framework that captures the role of TMs in effective KAM spanning across different areas of organizational function. Even though the study increases the complexity of capturing the factors that lead to effective KAM, at the same time it provides a deeper understanding of the underlying mechanisms of successful KAM relationships. 


\section{$\underline{\text { Managerial implications }}$}

TMs cannot stay isolated in their offices. Also, they should be sceptical and curious, challenge other's positions, be pragmatic, and be persuasive/polite when presenting their company's decisions to the top manager of a KA. Sceptical TMs never believe in the information or data collected by their KA manager or by the persons that work for their companies. A great deal of curiosity supports this scepticism. A curious TM tries to increase information quality and sources, as well as to promote internal and external debate about the solution alternatives presented or the evaluations carried out by their KA managers. TMs challenge others' positions by bargaining with their managers, with KAs, with banks or with government agencies. These bargains aim to improve their companies' returns. The limits to be observed in bargaining are dictated by analysis of their own companies, the KA and competitors. This analysis aims to explore every small possibility of increasing company gain. The persuasion of KA managers and their teams aims to remove internal resistances. Persuasive and polite TMs use prices or competitors' weaknesses to close deals or to induce the KA to redirect an unattractive order to competitors. Both actions are implanted carefully to preserve the buyer-customer relationship.

On a more general level the study provides guidance on how TMs can have the greatest influence on KAM success. TMs should participate in decision-making, coach, monitor and reward key account managers and teams, ensure internal coordination, empower organizational culture and structures that facilitate KAM function, and support the customer interface. KAM is not simply a sales or marketing task; rather, participation and coordination are required throughout the organization (Workman et al., 2003). The study suggests that TMs play a critical role in keeping everybody in the firm on the same page and supporting KAM function across all organizational areas (culture, structure, team selling, market offering) so as to achieve superior benefits from KAM relationships. 


\section{$\underline{\text { Limitations and further research }}$}

This investigation presents some limitations. First, this was an explorative and qualitative study with findings extracted from a limited number of companies. Second, the suppliers investigated were indicated by their customers due to their excellent performance (regarding B2B relationships and performance). Companies with lower performances in such indicators were not analysed. Third, generalization of the results should be treated with caution due to the limitations previously presented.

Further qualitative studies could investigate how TMs stimulate internal/external debate without generating conflicts or how KA managers perceive TM actions. Another research stream could investigate how TMs use competitors' weaknesses to reduce the chances of a price war, to define a price that induces a KA to direct an order to another supplier or to change its demand without damaging the buyer-supplier relationship. Any investigation of these gaps should consider how TMs use the following tactics: emotional (Curasi et al., 2018; Liu et al., 2018), coercive or rational (Liu et al., 2018). Future quantitative studies would allow for generalization of the results. An exploratory factor analysis to consider if the groups are empirically robust is also suggested. Generalization of the findings would help to identify how top managers engage in aligning KAM units internally (Pardo et al., 2013; Pilon and Hadjielias, 2017), improving the value delivered to KAs (Sharma, 2006; Zupancic, 2008), or mitigating internal resistance to KAM projects (Marcos-Cuevas et al., 2014; Pressey et al., 2014; Wilson and Woodburn, 2014). 


\section{References}

Abratt, R. and Kelly, P.M. (2002), "Customer-supplier partnerships. Perceptions of a successful key account management program", Industrial Marketing Management, Vol. 31 No. 5, pp. 467-476.

Adomako, S. (2017), “CEOs' regulatory foci and firm-level product innovativeness in competitive environments", Journal of Business \& Industrial Marketing, Vol. 32 No. 5, pp. 640-651.

ALHussan, F.B., AL-Husan, F.B. and Alhesan, L. (2017), "The role of senior executives in managing key customers in Arab context”, Journal of Business \& Industrial Marketing, Emerald Publishing Limited, Vol. 32 No. 6, pp. 825-835.

ALHussan, F.B., AL-Husan, F.B. and Fletcher-Chen, C.C.-Y. (2014), "Environmental factors influencing the management of key accounts in an Arab Middle Eastern context", Industrial Marketing Management, Elsevier, Vol. 43 No. 4, pp. 592-602.

Atanasova, Y. and Senn, C. (2011), "Global customer team design: Dimensions, determinants, and performance outcomes", Industrial Marketing Management, Elsevier, Vol. 40 No. 2, pp. $278-$ 289.

Baddar Al-Husan, F. and Brennan, R. (2009), "Strategic account management in an emerging economy”, Journal of Business \& Industrial Marketing, Vol. 24 No. 8, pp. 611-620.

Balboni, B. and Terho, H. (2016), "Outward-looking and future-oriented customer value potential management: The sales force value appropriation role", Industrial Marketing Management, Elsevier, Vol. 53, pp. 181-193.

Barney, J.B. (1986), “Organizational Culture: Can It Be a Source of Sustained Competitive Advantage?", The Academy of Management Review, Vol. 11 No. 3, p. 656.

Bates, T. and Bradford, W. (2009), "The impact of institutional sources of capital upon the minorityoriented venture capital industry”, Small Business Economics, Vol. 33 No. 4, pp. 485-496.

Birkinshaw, J., Toulan, O. and Arnold, D. (2001), "Global Account Management in Multinational Corporations: Theory and Evidence", Journal of International Business Studies, Palgrave Macmillan UK, Vol. 32 No. 2, pp. 231-248.

Blocker, C.P. and Flint, D.J. (2007), “Customer segments as moving targets: Integrating customer value dynamism into segment instability logic”, Industrial Marketing Management, Vol. 36 No. 6, pp. 810-822.

Blocker, C.P., Flint, D.J., Myers, M.B. and Slater, S.F. (2011), "Proactive customer orientation and 
its role for creating customer value in global markets", Journal of the Academy of Marketing Science, Springer US, Vol. 39 No. 2, pp. 216-233.

Blythe, J. (2002), "Using trade fairs in key account management", Industrial Marketing Management, Vol. 31 No. 7, pp. 627-635.

Boejgaard, J. and Ellegaard, C. (2010), “Unfolding implementation in industrial market segmentation”, Industrial Marketing Management, Vol. 39 No. 8, pp. 1291-1299.

Bradford, K.D., Challagalla, G.N., Hunter, G.K. and Moncrief, W.C. (2012), "Strategic Account Management: Conceptualizing, Integrating, and extending the Domain From Fluid to Dedicated accounts”, Journal of Personal Selling \& Sales Management, Routledge, Vol. 32 No. 1, pp. 4156.

Brehmer, P.-O. and Rehme, J. (2009), "Proactive and reactive: Drivers for key account management programmes", European Journal of Marketing, Vol. 43 No. 7, pp. 961-984.

Chakkol, M., Karatzas, A., Johnson, M. and Godsell, J. (2018), "Building bridges: boundary spanners in servitized supply chains", International Journal of Operations \& Production Management, Emerald Publishing Limited, Vol. 38 No. 2, available at:https://doi.org/10.1108/IJOPM-01-2016-0052.

Corbin, J. and Strauss, A. (2007), Basics of Qualitative Research: Techniques and Procedures for Developing Grounded Theory, Sage Publications.

Corbin, J.M. and Strauss, A. (1990), “Grounded theory research: Procedures, canons, and evaluative criteria", Qualitative Sociology, Kluwer Academic Publishers-Human Sciences Press, Vol. 13 No. 1, pp. 3-21.

Corsaro, D. and Snehota, I. (2010), "Searching for Relationship Value in Business Markets: Are We Missing Something?”, Industrial Marketing Management, Vol. 39 No. 6, pp. 986-995.

Corsaro, D. and Snehota, I. (2011), “Alignment and Misalignment in Business Relationships”, Industrial Marketing Management, Vol. 40 No. 6, pp. 1042-1054.

Crosno, J.L., Dahlstrom, R. and Manolis, C. (2015), “Comply or defy? An empirical investigation of change requests in buyer-supplier relationships", Journal of Business \& Industrial Marketing, Vol. 30 No. 5, pp. 688-699.

Curasi, C.F., Boles, J. and Reynolds, R. (2018), “Key account buying team members' emotional responses awarding multi-million dollar sales contracts", Industrial Marketing Management, 
Elsevier, available at:https://doi.org/10.1016/J.INDMARMAN.2018.05.005.

Davies, I.A. and Ryals, L.J. (2009), “A stage model for transitioning to KAM”, Journal of Marketing Management, Taylor \& Francis Group, Vol. 25 No. 9-10, pp. 1027-1048.

Davies, I.A. and Ryals, L.J. (2013), “Attitudes and behaviours of key account managers: Are they really any different to senior sales professionals?", Industrial Marketing Management, Vol. 42 No. 6, pp. 919-931.

Davies, I.A. and Ryals, L.J. (2014), “The effectiveness of Key Account Management practices”, Industrial Marketing Management, Vol. 43 No. 7, pp. 1182-1194.

Doz, Y. and Kosonen, M. (2007), "The new deal at the top”, Harvard Business Review, Vol. 85 No. 6, p. $98-104+142$.

Eisenhardt, K.M. (1989), “Building Theories from Case Study Research”, The Academy of Management Review, Vol. 14 No. 4, p. 532.

Eisenhardt, K.M. and Graebner, M.E. (2007), “Theory Building From Cases: Opportunities And Challenges", Academy of Management Journal, Vol. 50 No. 1, pp. 25-32.

Ellis, N. and Iwasaki, A. (2018), "Making sense of global key account management (GAM): a case study from Japan”, Journal of Business \& Industrial Marketing, Emerald Publishing Limited, Vol. 33 No. 7, pp. 1052-1064.

Flint, D.J.J., Blocker, C.P.P. and Boutin, P.J.J. (2011), “Customer value anticipation, customer satisfaction and loyalty: An empirical examination", Industrial Marketing Management, Vol. 40 No. 2, pp. 219-230.

Friend, S.B. and Johnson, J.S. (2014), "Key account relationships: An exploratory inquiry of customer-based evaluations", Industrial Marketing Management, Elsevier, Vol. 43 No. 4, pp. $642-658$.

Gartner Group. (2015), "Small and Midsize Business”, IT Glossary, available at: http://www.gartner.com/it-glossary/smbs-small-and-midsize-businesses (accessed 25 May 2015).

Georges, L. and Eggert, A. (2003), “Key Account Managers' Role Within the Value Creation Process of Collaborative Relationships", Journal of Business-to-Business Marketing, Taylor \& Francis Group, Vol. 10 No. 4, pp. 1-22.

Gosselin, D.P. and Bauwen, G.A. (2006), “Strategic account management: customer value creation 
through customer alignment", edited by Matthyssens, P.Journal of Business \& Industrial Marketing, Emerald Group Publishing Limited, Vol. 21 No. 6, pp. 376-385.

Gounaris, S. and Tzempelikos, N. (2013), "Key Account Management Orientation and Its Implications: A Conceptual and Empirical Examination”, Journal of Business-to-Business Marketing, Vol. 20 No. 1, pp. 33-50.

Gounaris, S. and Tzempelikos, N. (2014), "Relational key account management: Building key account management effectiveness through structural reformations and relationship management skills”, Industrial Marketing Management, Vol. 43 No. 7, pp. 1110-1123.

Guenzi, P., Georges, L. and Pardo, C. (2009), “The impact of strategic account managers' behaviors on relational outcomes: An empirical study", Industrial Marketing Management, Vol. 38 No. 3 , pp. $300-311$.

Guenzi, P., Pardo, C. and Georges, L. (2007), "Relational selling strategy and key account managers' relational behaviors: An exploratory study", Industrial Marketing Management, Vol. 36 No. 1, pp. 121-133.

Guenzi, P. and Storbacka, K. (2015), “The organizational implications of implementing key account management: A case-based examination”, Industrial Marketing Management, Vol. 45, pp. 8497.

Guesalaga, R. (2014), “Top management involvement with key accounts: The concept, its dimensions, and strategic outcomes", Industrial Marketing Management, Vol. 43 No. 7, pp. $1146-1156$.

Guesalaga, R. and Johnston, W. (2010), “What's next in key account management research? Building the bridge between the academic literature and the practitioners' priorities", Industrial Marketing Management, Vol. 39 No. 7, pp. 1063-1068.

Hakanen, T. (2014), "Co-creating integrated solutions within business networks: The KAM team as knowledge integrator”, Industrial Marketing Management, Vol. 43 No. 7, pp. 1195-1203.

Hald, K.S., Cordón, C. and Vollmann, T.E. (2009), “Towards an understanding of attraction in buyer-supplier relationships", Industrial Marketing Management, Vol. 38 No. 8, pp.960-970.

Harrison, D. and Kjellberg, H. (2010), "Segmenting a market in the making: Industrial market segmentation as construction”, Industrial Marketing Management, Vol. 39 No. 5, pp. 784-792.

Haytko, D.L. (2004), “Firm-to-Firm and Interpersonal Relationships: Perspectives from Advertising 
Agency Account Managers", Journal of the Academy of Marketing Science, Springer-Verlag, Vol. 32 No. 3, pp. 312-328.

Helander, A.. and Möller, K.. (2008), “System supplier’s roles from equipment supplier to performance provider", Journal of Business and Industrial Marketing, Vol. 23 No. 8, pp. $577-$ 585.

Henke, J.W., Parameswaran, R. and Mohan Pisharodi, R. (2008), "Manufacturer price reduction pressure and supplier relations", Journal of Business \&amp; Industrial Marketing, Vol. 23 No. 5, pp. 287-300.

Henneberg, S.C., Pardo, C., Mouzas, S. and Naudé, P. (2009), "Value dimensions and relationship postures in dyadic 'Key Relationship Programmes"”, Journal of Marketing Management, Taylor \& Francis Group, Vol. 25 No. 5-6, pp. 535-550.

Hirschman, E. (1986), "Humanistic inquiry in marketing research: Philosophy, method, and criteria", Journal of Marketing Research, Vol. 23, pp. 237-249.

Hollmann, T., Jarvis, C.B. and Bitner, M.J. (2015), "Reaching the breaking point: a dynamic process theory of business-to-business customer defection", Journal of the Academy of Marketing Science, Vol. 43 No. 2, pp. 257-278.

Homburg, C., Workman, J.P. and Jensen, O. (2002), “A Configurational Perspective on Key Account Management”, Journal of Marketing, SAGE PublicationsSage CA: Los Angeles, CA, Vol. 66 No. 2, pp. 38-60.

Hsieh, M.-H. and Chou, W.-C. (2011), "Managing key account portfolios across the process of relationship development: A value proposition-desired value alignment perspective", Journal of Business-to-Business Marketing, Vol. 18 No. 1, pp. 83-119.

Ivens, B. and Pardo, C. (2008), "Key-account-management in business markets: An empirical test of common assumptions", Journal of Business and Industrial Marketing, Vol. 23 No. 5, pp. 301310.

Ivens, B.S., Leischnig, A., Pardo, C. and Niersbach, B. (2018), "Key account management as a firm capability”, Industrial Marketing Management, Elsevier, Vol. 74, pp. 39-49.

Ivens, B.S., Pardo, C., Salle, R. and Cova, B. (2009), "Relationship keyness: The underlying concept for different forms of key relationship management", Industrial Marketing Management, Vol. 38 No. 5, pp. 513-519. 
Jean, R.-J. “Bryan”, Sinkovics, R.R., Kim, D. and Lew, Y.K. (2015), “Drivers and performance implications of international key account management capability", International Business Review, Pergamon, Vol. 24 No. 4, pp. 543-555.

Kamp, B. (2005), "Formation and evolution of buyer-supplier relationships: Conceiving dynamism in actor composition of business networks", Industrial Marketing Management, Vol. 34 No. 7 , pp. 658-668.

Kotter, J. and Schlesinger, L. (2008), “Choosing Strategies for Change”, Harvard Business Review, Vol. 86 No. 7-8, p. 130-139+162.

Leischnig, A., Ivens, B.S., Niersbach, B. and Pardo, C. (2018), "Mind the gap: A process model for diagnosing barriers to key account management implementation", Industrial Marketing Management, Elsevier, Vol. 70, pp. 58-67.

Liu, Y., Huang, Y. and Fan, H. (2018), "Influence tactics, relational conditions, and key account managers' performance”, Industrial Marketing Management, Elsevier, Vol. 73, pp. 220-231.

Makkonen, H., Vuori, M. and Puranen, M. (2016), "Buyer attractiveness as a catalyst for buyersupplier relationshipdevelopment”, Industrial Marketing Management, Vol. 55, pp. 156-168.

Marcos-Cuevas, J., Nätti, S., Palo, T. and Ryals, L.J. (2014), “Implementing key account management: Intraorganizational practices and associated dilemmas", Industrial Marketing Management, Vol. 43 No. 7, pp. 1216-1224.

Miles, M.B. and Huberman, A.M. (2004), Qualitative Data Analysis: An Expanded Sourcebook, 2nd editio., SAGE Publications, Inc, Thousand Oaks, CA.

Millman, T. and Wilson, K. (1999), "Processual issues in key account management: underpinning the customer-facing organisation", Journal of Business \& Industrial Marketing, MCB UP Ltd, Vol. 14 No. 4, pp. 328-344.

Mortensen, M.H. (2012), "Understanding attractiveness in business relationships - A complete literature review", Industrial Marketing Management, Elsevier Inc., Vol. 41 No. 8, pp. 12061218.

Murfield, M.L.U. and Esper, T.L. (2016), "Supplier adaptation: A qualitative investigation of customer and supplier perspectives”, Industrial Marketing Management, Vol. 59, pp. 96-106.

Murphy, W.H. and Li, N. (2015), "Key account management in China: Insights from a Chinese supplier", Journal of Business Research, Vol. 68 No. 6, pp. 1234-1241. 
Nätti, S. and Palo, T. (2012), "Key account management in business-to-business expert organisations: an exploratory study on the implementation process", The Service Industries Journal, Vol. 32 No. 11, pp. 1837-1852.

Neto, G.Z., Pereira, G.M. and Borchardt, M. (2015), "What Problems Manufacturing Companies can Face when Providing Services around the World?", Journal of Business \& Industrial Marketing, Vol. 30 No. 5, pp. 461-471.

Niraj, R., Foster, G., Gupta, M.R. and Narasimhan, C. (2008), "Understanding customer level profitability implications of satisfaction programs", Journal of Business \& Industrial Marketing, Vol. 23 No. 7, pp. 454-463.

Ojasalo, J. (2001), "Key account management at company and individual levels in business-tobusiness relationships", Journal of Business and Industrial Marketing, Vol. 16 No. 3, pp. 199218.

Oliva, R.A. (2006), “The three key linkages: improving the connections between marketing and sales", edited by Matthyssens, P.Journal of Business and Industrial Marketing, Emerald Group Publishing Limited, Vol. 21 No. 6, pp. 395-398.

Pache, A.-C. and Santos, S.F.O.M. (2010), "When worlds collide: The internal dynamics of organizational responses to conflicting institutional demands", Academy of Management Review, Vol. 35 No. 3, pp. 455-476.

Paiola, M., Gebauer, H. and Edvardsson, B. (2012), "Service Business Development in Small- to Medium-Sized Equipment Manufacturers”, Journal of Business-to-Business Marketing, Vol. 19 No. 1, pp. 33-66.

Pardo, C., Ivens, B. and Wilson, K. (2014), "Differentiation and alignment in KAM implementation”, Industrial Marketing Management, Vol. 43 No. 7, pp. 1136-1145.

Pardo, C., Ivens, B.S. and Wilson, K. (2013), “Assessing and strengthening internal alignment of new marketing units: An interpretative tool”, Industrial Marketing Management, Elsevier, Vol. 42 No. 7, pp. 1074-1082.

Patton, M. (2002), Qualitative Research \& Evaluation Methods, 4 Ed., Sage Pubns, Saint Paul, MN. Pereira, G.M., Rocha, M., Nunes, F.L., Borchardt, M. and Viegas, C.V. (2018), “Internal elements that hinder a better industrial service offering”, Journal of Business \& Industrial Marketing, Vol. 33 No. 2, pp. 220-227. 
Pick, D. and Eisend, M. (2014), “Buyers' perceived switching costs and switching: A meta-analytic assessment of their antecedents", Journal of the Academy of Marketing Science, Vol. 42 No. 2, pp. 186-204.

Piercy, N. and Lane, N. (2006), “The Underlying Vulnerabilities in Key Account Management Strategies”, European Management Journal, Pergamon, Vol. 24 No. 2-3, pp. 151-162.

Piercy, N.F. (2009), “Strategic relationships between boundary-spanning functions: Aligning customer relationship management with supplier relationship management”, Industrial Marketing Management, Elsevier, Vol. 38 No. 8, pp. 857-864.

Pilon, F. and Hadjielias, E. (2017), "Strategic account management as a value co-creation selling model in the pharmaceutical industry", Journal of Business \& Industrial Marketing, Emerald Publishing Limited, Vol. 32 No. 2, pp. 310-325.

Powers, T.L. and Sterling, J.U. (2008), "Segmenting business-to-business markets: A micro-macro linking methodology”, Journal of Business and Industrial Marketing, Vol. 23 No. 3, pp. 170177.

Preikschas, M.W., Cabanelas, P., Rüdiger, K. and Lampón, J.F. (2017), "Value co-creation, dynamic capabilities and customer retention in industrial markets", Journal of Business and Industrial Marketing, Vol. 32 No. 3, pp. 409-420.

Pressey, A., Tzokas, N. and Winklhofer, H. (2007), "Strategic purchasing and the evaluation of ‘problem' key supply relationships: What do key suppliers need to know?”, Journal of Business \&amp; Industrial Marketing, Vol. 22 No. 5, pp. 282-294.

Pressey, A.D., Gilchrist, A.J.P. and Lenney, P. (2014), "Sales and marketing resistance to Key Account Management implementation: An ethnographic investigation”, Industrial Marketing Management, Vol. 43 No. 7, pp. 1157-1171.

Rabetino, R., Kohtamäki, M. and Gebauer, H. (2017), “Strategy map of servitization”, International Journal of Production Economics, Elsevier, Vol. 192, pp. 144-156.

Rehme, J., Kowalkowski, C. and Nordigården, D. (2013), "Sales coordination and structural complexity: a national-international comparison", edited by Brashear Alejandro, T.Journal of Business \& Industrial Marketing, Emerald Group Publishing Limited, Vol. 28 No. 6, pp. 514522.

Richards, K.A. and Jones, E. (2009), "Key Account Management: Adding Elements of Account Fit to an Integrative Theoretical Framework", Journal of Personal Selling \& Sales Management, 
Routledge, Vol. 29 No. 4, pp. 305-320.

Ritter, T. and Andersen, H. (2014), “A relationship strategy perspective on relationship portfolios:

Linking customer profitability, commitment, and growth potential to relationship strategy", Industrial Marketing Management, Vol. 43 No. 6, pp. 1005-1011.

Rocca, A.L., Caruana, A., Snehota, I., La Rocca, A., Caruana, A. and Snehota, I. (2012), "Measuring customer attractiveness", Industrial Marketing Management, Vol. 41 No. 8, pp. 1241-1248.

Ryals, L. and Rogers, B. (2007), "Key account planning: benefits, barriers and best practice", Journal of Strategic Marketing, Taylor \& Francis, Vol. 15 No. 2-3, pp. 209-222.

Ryals, L.J. and Davies, I. a. (2013), “Where's the strategic intent in key account relationships?”, Journal of Business \& Industrial Marketing, Vol. 28 No. 2, pp. 111-124.

Ryals, L.J. and Holt, S. (2007), “Creating and capturing value in KAM relationships”, Journal of Strategic Marketing, Routledge, Vol. 15 No. 5, pp. 403-420.

Saldaña, J. (2015), The Coding Manual for Qualitative Researchers, Sage.

Salojärvi, H., Saarenketo, S. and Puumalainen, K. (2013), "How customer knowledge dissemination links to KAM", Journal of Business and Industrial Marketing, Vol. 28 No. 5, pp. 383-395.

Salojärvi, H., Sainio, L.-M. and Tarkiainen, A. (2010), “Organizational factors enhancing customer knowledge utilization in the management of key account relationships", Industrial Marketing Management, Vol. 39 No. 8, pp. 1395-1402.

Sarkees, M. (2011), "Understanding the links between technological opportunism, marketing emphasis and firm performance: Implications for B2B”, Industrial Marketing Management, Vol. 40 No. 5, pp. 785-795.

Scheer, L.K., Miao, C.F. and Garrett, J. (2010), "The effects of supplier capabilities on industrial customers' loyalty: The role of dependence", Journal of the Academy of Marketing Science, Vol. 38 No. 1, pp. 90-104.

Sharma, A. (2006), "Success factors in key accounts", Proceedings of the European Conference on E-Government, ECEG, pp. 77-85.

Sharma, A. and Evanschitzky, H. (2016), "Returns on key accounts: do the results justify the expenditures?”, Journal of Business \& Industrial Marketing, Emerald Group Publishing Limited, Vol. 31 No. 2, pp. 174-182.

Shi, L.H., White, J.C., McNally, R.C., Tamer Cavusgil, S. and Zou, S. (2005), “Executive Insights: 
Global Account Management Capability: Insights from Leading Suppliers”, Journal of International Marketing, American Marketing Association, Vol. 13 No. 2, pp. 93-113.

Shi, L.H., White, J.C., Zou, S. and Cavusgil, S.T. (2010), “Global account management strategies: Drivers and outcomes", Journal of International Business Studies, Palgrave Macmillan UK, Vol. 41 No. 4, pp. 620-638.

Simkin, L. (2008), “Achieving market segmentation from B2B sectorisation”, Journal of Business and Industrial Marketing, Vol. 23 No. 7, pp. 464-474.

Spencer, R. (1999), "Key accounts: effectively managing strategic complexity”, Journal of Business \& Industrial Marketing, MCB UP Ltd, Vol. 14 No. 4, pp. 291-310.

Steward, M.D., Wu, Z. and Hartley, J.L. (2010), "Exploring supply managers’ intrapreneurial ability and relationship quality", Journal of Business-to-Business Marketing, Vol. 17 No. 2, pp. 127148.

Stock, R.M. (2006), "Interorganizational teams as boundary spanners between supplier and customer companies”, Journal of the Academy of Marketing Science, Vol. 34 No. 4, pp. 588-599.

Storbacka, K. (2012), "Strategic account management programs: alignment of design elements and management practices”, Journal of Business \& Industrial Marketing, Vol. 27 No. 4, pp. 259274.

Strauss, A. and Corbin, J. (1998), Basics of Qualitative Research: Techniques and Procedures for Developing Grounded Theory. Sage Publications, Thousand Oaks, CA.

Sullivan, U.Y., Peterson, R.M. and Krishnan, V. (2012), "Value creation and firm sales performance: The mediating roles of strategic account management and relationship perception", Industrial Marketing Management, Elsevier Inc., Vol. 41 No. 1, pp. 166-173.

Thomas, R.J. (2016), "Multistage market segmentation: an exploration of B2B segment alignment", Journal of Business and Industrial Marketing, Vol. 31 No. 7, pp. 821-834.

Toulan, O., Birkinshaw, J. and Arnold, D. (2006), "The Role of Interorganizational Fit in Global Account Management”, International Studies of Management \& Organization, Routledge, Vol. 36 No. 4, pp. 61-81.

Tzempelikos, N. (2015), “Top management commitment and involvement and their link to key account management effectiveness", Journal of Business \& Industrial Marketing, Vol. 30 No. 1, pp. $32-44$. 
Tzempelikos, N. and Gounaris, S. (2013), “Approaching Key Account Management from a longterm perspective", Journal of Strategic Marketing, Vol. 21 No. 2, pp. 179-198.

Tzempelikos, N. and Gounaris, S. (2015), "Linking key account management practices to performance outcomes", Industrial Marketing Management, Vol. 45, pp. 22-34.

Vanharanta, M., J.P. Gilchrist, A., D. Pressey, A. and Lenney, P. (2014), “The reflexive turn in key account management”, European Journal of Marketing, Emerald Group Publishing Limited, Vol. 48 No. 11/12, pp. 2071-2104.

Viio, P. and Grönroos, C. (2015), "How buyer-seller relationship orientation affects adaptation of sales processes to the buying process", Industrial Marketing Management, available at:https://doi.org/10.1016/j.indmarman.2015.07.013.

Wagner, E.R. and Hansen, E.N. (2004), "A method for identifying and assessing key customer group needs", Industrial Marketing Management, Elsevier, Vol. 33 No. 7, pp. 643-655.

Wallendorf, M. and Belk, R. (1989), “Assessing trustworthiness in naturalistic consumer research”, Interpretive Consumer Research, pp. 69-84.

Wang, X.L. and Brennan, R. (2014), “A framework for key account management and revenue management integration", Industrial Marketing Management, Elsevier B.V., Vol. 43 No. 7, pp. $1172-1181$.

Wengler, S., Ehret, M. and Saab, S. (2006), "Implementation of Key Account Management: Who, why, and how? An exploratory study on the current implementation of Key Account Management programs”, Industrial Marketing Management, Vol. 35 No. 1, pp. 103-112.

Wießmeier, G.F.L., Thoma, A. and Senn, C. (2012), "Leveraging Synergies Between R\&amp;D and Key Account Management to Drive Value Creation", Research-Technology Management, Taylor \& Francis, Vol. 55 No. 3, pp. 15-22.

Wilson, K. and Woodburn, D. (2014), “The impact of organisational context on the failure of key and strategic account management programmes", Journal of Business \& Industrial Marketing, Vol. 29 No. 5, pp. 353-363.

Workman, J.P., Homburg, C. and Jensen, O. (2003), "Intraorganizational Determinants of Key Account Management Effectiveness", Journal of the Academy of Marketing Science, Vol. 31 No. 1, pp. 3-21.

Yin, R.K. (2009), Case Study Research: Design and Methods, Thousand Oaks, CA: Sage 
Publications., Sage Publications, Thousand Oaks, CA, CA.

Zupancic, D. (2008), “Towards an integrated framework of key account management”, Journal of Business \& Industrial Marketing, Vol. 23 No. 5, pp. 323-331.

Zupancic, D. and Mullner, M. (2008), "International key account management in manufacturing companies: An exploratory approach of situative differentiation", Journal of Business-toBusiness Marketing, Vol. 15 No. 4, pp. 455-475. 


\section{$\underline{\text { Appendix } 1 \text { - Open-ended questions }}$}

1. What a TM could do to improve their KA managers and team?

2. What a TM could do to improve the internal culture?

3. What a TM could do to improve to the subordinates' engagement?

4. What a TM could do to improve the knowledge?

5. What a TM could do to improve the Organizational structure/conditions?

6. What a TM could do to improve the market's analysis? 